\title{
New Vision of New Sources
}

\author{
Awatif Aljudaibi* \\ Department of biological science, microbiology section-KAU, Saudi Arabia
}

Submission: October 16, 2017; Published: March 20, 2018

*Corresponding author: Awatif Aljudaibi, Department of biological science, microbiology section-KAU, Saudi Arabia, Email: aamaljudaibi@kau.edu.sa

\section{Review}

Fresh, clean food is important to good nutrition. Preventing food from becoming contaminated with food poisoning bacteria reduces losses and illnesses. Bacteria in food can reduce the food's nutrient value and also cause disease. Bacteria that cause disease are called pathogenic bacteria. Bacteria can cause diseases in humans, in other animals, and also in plants. Some bacteria can only make one particular host ill; others cause trouble in a number of hosts, depending on the host specificity of the bacteria. The diseases caused by bacteria include food poisoning, tooth ache anthrax, even certain forms of cancer. Disease causing (or pathogenic) bacteria can contaminate food and water and cause food poisoning in the form of diseases such as typhoid, cholera and hepatitis. Pathogenic bacteria are sometimes represented as (deadly) dangerous enemies that lurk in the dark, unseen, ready to attack. Some bacteria kill a high percentage of people infected. Bacteria have invented many different strategies to make us ill. These strategies are called bacterial pathogenicity.

Microbial contaminated food is a problem, fast foods and restaurants are not committed to food storage and workers' health. A report from the Saudi Food and Drug Authority indicates that there are approximately 5,000 cases of food poisoning per year in Saudi Arabia [1]. The symptoms of food poisoning commonly include nausea, vomiting, abdominal pain, diarrhoea and fever, although not all of them may occur in every case. Symptoms vary depending upon the cause and usually start between one and 36 hours after eating the contaminated food and may last for several days. Food poisoning may be fatal, depending upon the cause and the overall fitness of the sick person. Some bacteria, for example most salmonella bacteria, can increase in numbers in food very rapidly under some circumstances. Contamination of foods is a common cause of outbreaks of food poisoning. Food that is contaminated with large numbers of bacteria can be a source of contamination of other foods. Contamination of foods can happen when food contaminated by hands, flies or other insects or pests touches a clean food or when clean foods touch a contaminated surface or utensil.

Raw foods including meat, poultry, fish and shellfish, eggs, unpasteurized milk and dairy products, and fresh produce often contain bacteria that cause food borne illnesses. Foods may also be contaminated with bacteria during food preparation in a restaurant or home kitchen. If food preparers do not thoroughly wash their hands, kitchen utensils, cutting boards, and other kitchen surfaces that come into contact with raw foods, cross contamination and the spread of bacteria from contaminated food to uncontaminated food may occur. Many types of bacteria cause food borne illnesses [2]. Examples include: Salmonella (a bacterium present on egg shells and inside eggs), Campylobacter jejuni (found in raw or undercooked chicken and unpasteurized milk), Shigella (a bacterium spread from person to person), Escherichia coli (present in raw or undercooked hamburger, unpasteurized fruit juices and milk, and fresh produce), Listeria monocytogenes (found in raw and undercooked meats, unpasteurized milk, soft cheeses, and ready-to-eat deli meats and hot dogs), Vibrio (a bacterium that may contaminate fish or shellfish), Clostridium botulinum (contaminate improperly canned foods and smoked and salted fish).

Each year, an estimated 48 million people in the United States experience a food borne illness. Food borne illnesses cause about 3,000 deaths in the United States annually [3]. Botulism, microbial food poisoning due to Clostridium botulinum, is one of the more well-known food borne diseases due to the severe nature of the illness. As C. botulinum grows in food it produces a neurotoxin, which causes symptoms approximately 12-36 hours after consumption. In the past botulism was mainly associated with canned foods, but it has recently also been associated with vegetables in oil and some other foods. Staphylococcus aureus also known as 'Golden staph' is important from both a medical and food perspective. About half of us carry this organism on our skin and in nasal passages. Infected cuts or sores can contain large numbers of $S$. aureus, and such wounds should be kept 
well covered if a person is handling foods. Animals, including poultry, also carry this bacteria on their bodies, and all raw meat and poultry products should be handled as though they are contaminated. Raw milk can also be a source of this bacteria [4]. Certain gut microflora such as Escherichia coli, Pseudomonas aeroginosa, Klebsiella sp., Streptococcus sp., Salmonella spp., and Shigella sp. can cause food poisoning if the food is contaminated with these bacteria. Environmental contamination potentially leads to human or animal illness, and one direct route of contamination is from manure used as an agriculture fertilizer. The concentration of resistant E. coli in feces varies enormously between individuals [5-8].

As a consequence there is much that still needs to be understood about the behavior and pathogenicity of these highly important bacteria. In particular, and from a food industry/ food safety perspective, it is important to better understand the behavior of bacteria, and how to control it. Harmful gut microbiome is devoiced manure. If contaminated produce is not processed, it may contain some of the gut microorganisms when it reaches the supermarket. Manure can cause contamination in food even when not used as fertilizer. In addition, raw milk can be contaminated during the milking process. Contamination of food can also come through water, spraying contaminated water on plants to irrigate, wash, or chill them can contaminate foods, especially leafy green vegetables, are grown in water that has been contaminated by manure, bacteria can adhere to their surfaces and become extremely difficult to wash off. In some cases, they can find their way inside the vegetables' cells where washing will have no effect. Water is not only a problem on the farm; it is used in food processing, or even to wash food at the supermarket.

Patients who have bacterial infected are usually with antibiotics, and the continuing use of antibiotics produces bacteria that can resist the antibiotics. Decreased efficiency and resistance of pathogen to antibiotics has necessitated the development of new alternatives. Moreover, the cost of the drugs is high and also they cause adverse effect on the host, which include hypersensitivity and depletion of beneficial microbes in the gut. There are several sources in nature of compounds that can inhibit pathogenic bacterial growth, and these may provide new antibiotic medicines.

Nowadays there is an increasing demand for biodiversity in the screening programs for selecting therapeutic drugs from natural products, the marine organisms; especially seaweeds are of with immense interest, since they are having a broad range of biological activities such as antibacterial, antifungal, antiviral, antitumorals, anti-inflammatory and antioxidants. Seaweeds have been recognized as potential sources of antibiotic substances. The production of antimicrobial activities was considered to be an indicator of the seaweeds to synthesize bioactive secondary metabolites [8-10].
Marine algae represent an inexhaustible reservoir of raw materials used in pharmaceutical, medicine, food industries and cosmetics [11]. Marine algae serve as an important source of bioactive natural substances $[12,13]$. Special attention has been reported on antibacterial activities related to marine seaweeds against several pathogens [14]. The antibacterial activity of methanolic extracts from 20 species of macroalgae including Chlorophyta, Phaeophyta and Rhodophyta was evaluated against E. coli, S. aureus and E. faecalis [15]. Study results indicated that seaweeds have presented a significant capacity of antibacterial activities, which makes them interesting for screening for natural products. The extracts and active constituents of various marine seaweeds have been shown to have antibacterial activity against Gram positive and Gram negative bacteria [16,17]. The antimicrobial compounds derived from the marine seaweeds consist of a diverse group of chemical compounds [18]. Many substances obtained from marine algae such as alginate, carrageenan and agar as phycocolliods have been used for decades in medicine and pharmacy [19]. Chemical structure types include sterols [20], isoprenoide, amino acids, terpenoids, phlorotannins, steroids, phenolic compounds, fatty acids and acrylic acid can be counted [21]. Numerous substances were identified as antimicrobial agents from algae such as Chlorellin derivatives, acrylic acid, halogenated aliphatic compounds, terpenes, sulphur containing heterocylic compounds, phenolic inhibitors etc.

Medical plants are widely used in the treatment of various diseases in today's world. Plant extracts and their various formulations in the treatment and/or alleviation of several diseases in folk medicine have been dated back to the ancient times. Besides, some natural products also exist in vegetables, fruits and beverages [22]. Medical plants initially draw attention as antimicrobial agents with the extraction of the active compound and essential oils. In a study on 66 essential oils and compounds that exhibited $\geq 80 \%$ inhibition towards Salmonella typhimurium DT104 and E. coli 0157: H7, nine were further studied [23]. They showed that most of the oils and compounds demonstrated high efficacy against $S$. typhimurium DT104, E. coli 0157: H7, and E. coli with K88 pili. In addition, they significantly inhibited E. coli and coliform bacteria in the digest, but had little effect on the total number of lactobacilli and anaerobic bacteria. The chemical composition of the essential oil from the leaves of Pelargonium odoratissimum (L.) L'Hér., Geraniaceae, was determined and the antimicrobial activities against the $S$. aureus ATCC 25923 and E. coli ATCC 25992 were evaluated and exhibited an effect on the bacteria at the concentrations tested [24].

\section{References}

1. http://www.aleqtisadiah.com

2. http://digestive.niddk.nih.gov/ddiseases/pubs/bacteria/ 
3. Scallan E, Griffin PM, Angulo FJ, Tauxe RV, Hoekstra RM, et al. (2011) Foodborne illness acquired in the United States-unspecified agents. Emerg Infect Dis 17(7): 1338-1340.

4. Forssa N, Ramstadb R, Bäcklundc T, Lindströmf M, Kolhod E, et al. (2012) Difficulties in Diagnosing Food-Borne Botulism. Case Rep Neurol 4: 113-115.

5. Gibson GR, Wang X (1994) Enrichment of bifidobacteria from human gut contents by oligofructose using continuous culture. FEMS Microbiol Lett 118(1-2): 121-127.

6. Gibson GR, Saavedra JM, Macfarlane S, Macfarlane GT (1997) Gastrointestinal microbial disease. Pathog Dis 67(1): 25-38.

7. Finley R, Ribble C, Aramini J, Vandermeer M, Popa M, et al. (2007) The risk of salmonellae shedding by dogs fed Salmonella-contaminated commercial raw food diets. Can Vet J 48(1): 69-75.

8. Mann MD, Crouse, DA, Prentice et al. (1991) Apprapriate animal numbers in biomedical research in light of animal weifare considerations. Lab Anim Sci 41(1): 6-14.

9. Edmond MB, Ober JF, Weinbaum DL, Pfaller MA, Hwang T, et al. (1995) Vancomycin-resistant Enterococcus faecium bacteremia. Clin Infect Dis 20: 1126-1133.

10. Humphrey T, O Brien S, Madsen M (2007) Campylobacters as zoonotic pathogens: A food production perspective. Int J Food Microbiol 117(3): 237-257.

11. Badea V, Balaban DP, Rapeanu G, Maria C, Badea CF, et al. (2009) The antibacterial activity evaluation of Cystoseira barbata biomass and some agents upon bacteria from oropharyngeal cavity. Rom Soc Bio Sci 14(6): 4851-4857.

12. Vijayabaskar P, Shiyamala V (2011) Antibacterial activities of brown marine algae (Sargassum wightii and Turbinaria ornata) from the Gulf of Mannar. Biosphere Reserve. Adv Biol Res 5(2): 99-102.

13. Villarreal Gómez LJ, Irma EM, Graciela GR, Nahara ES (2010) Antibacterial and anticancer activity of seaweeds and bacteria associated with their surface. Rev biol mar oceanogr 45(2): 267-275.
14. Siddhanta AK, Mody KH, Ramavat BK, Chauhan VD, Garg HS etal. (1997) Bioactivity of marine organisms: Part VIII - Screening of some marine flora of western coast of India. Indian J Exp Biol. 35(6): 638-43.

15. Devi GK, Manivannan K, Thirumaran G,. Rajathi FAA, AnantharamanP et al. (2011) In vitro antioxidant activities of selected seaweeds from Southeast coast of India. Asian Pac J Trop Med 4(3): 205-211.

16. Lima Filho JV, Carvalho AF, Freitas SM (2002) Antibacterial activity of extracts of six macroalgae from the Northeastern Brazilian Coast. Brazilian J Microbiol 33: 311-313.

17. Paul G, Yusuf S, Sharma S. (2006). Unmasking of the Brugada syndrome phenotype during the acute phase of amiodarone infusion. Circulation 114(11): 489-491.

18. Nor Afifah S, Sarah I, Shade FS, Mohd Jain NM, Nurul AZ, et al. (2010) Antimicrobial activity of various extracts of a tropical Chlorophyta macroalgae, Halimeda discoidea. J Appl Sci 10(23): 3007-3013.

19. Taskin E, Ozturk M, Kurt O (2001) Turkiye'nin yararlanilabilir denizel alg potansiyeli. XI. Ulusal Su Urunleri Sempozyumu (4-6 Eylul 2001, Antakya). 225-232.

20. Ahmed VU, Aliya R, Perveen S, Samuel M (1993) Stereoids from marine green alga Codium decortacatum. Phytochem 33: 1189-1192.

21. Mtolera MS, Semesi AK (1996) Antimicrobial activity of extracts from six green algae from Tanzania. Curr Trends Mar Bot. East Afr.

22. Oz AT (2010) Effects of harvest date and conditions of storage of Hayward kiwifruits on contents of L-ascorbic acid. J Food Agric Environ 8: 132-134.

23. Si W, Gong J, Tsao R, Zhou T, Yu H, et al. (2006) Antimicrobial activity of essential oils and structurally related synthetic food additives towards selected pathogenic and beneficial gut bacteria. Journal of Applied Microbiology 100: 296-305.

24. Andrade MA, Cardoso MG, Batista LR, Freire JM, Nelson DL, et al (2011) Antimicrobial activity and chemical composition of essential oil of Pelargonium odoratissimum. Brazilian Journal of Pharmacognosy 21(1): 47-52.

\section{Your next submission with Juniper Publishers will reach you the below assets}

- Quality Editorial service

- Swift Peer Review

- Reprints availability

- E-prints Service

- Manuscript Podcast for convenient understanding

- Global attainment for your research

- Manuscript accessibility in different formats ( Pdf, E-pub, Full Text, Audio)

- Unceasing customer service

Track the below URL for one-step submission https://juniperpublishers.com/online-submission.php 